\title{
ULTRAMICROSCOPIC STRUCTURE OF THE RHEUMATOID NODULE
}

\author{
BY \\ W. COCHRANE, D. V. DAVIES, J. DORLING, AND E. G. L. BYWATERS \\ From St. Thomas's Hospital Medical School, London, and The Medical Research Council \\ Rheumatism Research Unit, Taplow, Berkshire
}

Rheumatoid nodules develop over bony prominences, particularly at the elbow; they grow slowly and show little tendency to disappear. They have been well described by Collins (1939) and by Bennett, Zeller, and Bauer (1940). The established nodule consists of a central necrotic zone in which there has been described "fibrinoid degeneration", "swelling and fragmentation of collagen fibrils", and "fibrinous exudation". Around this central area is a highly cellular zone where the cells, characterized as fibroblasts or histiocytes, are arranged in radial fashion to form the palisade layer, sometimes called "boundary zone" or "corona". Beyond this is a loose fibrous capsular zone, rich in mature fibroblasts, collagen, and blood vessels, and lightly infiltrated with inflammatory cells (lymphocytes, plasma cells, and some mast cells). The nodule has been thought to grow by extension of the central necrotic area at the expense of the palisade layer of cells which recedes centrifugally. This extension appears to occur in waves, seen under the light microscope as differentially staining concentric bands in the necrotic region. Blood vessels in the periphery of the nodule may occasionally show obliterative or arteritic changes, as Sokoloff has emphasized (Sokoloff and Bunim, 1957), but the vast majority of arteries and other vessels seen in most of the nodule sections studied by us have been intact, both outside the palisade layer, and although necrotic, in the necrotic centre.

The nature and composition of the necrotic zone has been studied histologically, biochemically, immunologically, and by $x$-ray diffraction, with varying conclusions. Apart from a study of fibres taken from such an area by Kellgren, Ball, Astbury, Reed, and Beighton (1951), no ultramicroscopic study has yet appeared. This present investigation is concerned primarily with the fine structure of the necrotic centre in an attempt to define its components morphologically and to elucidate its mode of development.

\section{Material and Methods}

The material examined consisted of biopsy specimens from seven cases of classical sero-positive rheumatoid arthritis from the Medical Research Council Rheumatism Research Unit at Taplow. Table I shows the age of the patients, duration of the disease, past gold therapy, if any, and present treatment with steroids.

TABLE I

DETAILS OF MATERIAL

\begin{tabular}{|c|c|c|c|c|c|}
\hline \multirow{2}{*}{ Case No. } & \multirow{2}{*}{ Sex } & \multirow{2}{*}{$\begin{array}{c}\text { Age } \\
\text { (yrs) }\end{array}$} & \multirow{2}{*}{$\begin{array}{l}\text { Duration of } \\
\text { Disease (yrs) }\end{array}$} & \multicolumn{2}{|c|}{ Past Therapy } \\
\hline & & & & Gold & $\begin{array}{c}\text { Steroids } \\
\text { (yrs) }\end{array}$ \\
\hline $\begin{array}{l}1 \\
2 \\
3 \\
4 \\
5 \\
6 \\
7\end{array}$ & $\begin{array}{l}\mathbf{F} \\
\mathbf{M} \\
\mathbf{F} \\
\mathbf{F} \\
\mathbf{F} \\
\mathbf{F} \\
\mathbf{M}\end{array}$ & $\begin{array}{l}64 \\
61 \\
44 \\
55 \\
59 \\
68 \\
46\end{array}$ & $\begin{array}{l}31 \\
2 \\
9 \\
37 \\
20 \\
8 \\
9 / 12\end{array}$ & $\begin{array}{l}0 \\
0 \\
+ \\
0 \\
+ \\
0 \\
0\end{array}$ & $\begin{array}{l}0 \\
0 \\
0 \\
5 \\
2 \\
7 \\
0\end{array}$ \\
\hline
\end{tabular}

The nodules were removed from the elbow region by open biopsy with a tourniquet in position. From fresh slices of material, small pieces, not larger than $1 \mathrm{~mm} .{ }^{3}$ were removed with a punch for electron microscopy. The remainder of the tissue was fixed in 10 per cent. buffered formalin. Portions including the punch hole were imbedded in paraffin wax, sectioned at $8 \mu$ and stained by the following methods:

1. Haematoxylin and eosin for general orientation.

2. Mallory's azo-carmine, which stains fibrin and fibrinoid red against a blue collagen background.

3. Mallory's phosphotungstic acid-haematoxylin for fibrin.

4. Paps silver impregnation for reticulin.

5. Periodic acid-Schiff reaction.

6. Azur A, occasionally.

7. Orcein for elastic tissue.

In some cases other portions of the biopsy material were cut on the freezing microtome and the sections coloured with Scharlach $\mathbf{R}$ for lipids.

The tissue for electron microscopy was fixed with minimum delay in 1 per cent. osmium tetroxide, buffered at pH 7.4 (Zetterquist, 1956) for 1 to 2 hours, dehydrated 
in graded ethyl alcohols, and then transferred into a mixture of equal volumes of absolute alcohol and propylene oxide for $30 \mathrm{~min}$. and embedded in Araldite.

Thick $1 \mu$ sections and ultrathin sections were cut on the Leitz ultramicrotome. The thick sections were mounted on glass slides and stained with Mallory's azure II-methylene blue mixture (Richardson, Jarett, and Finke, 1960). The ultrathin sections were picked up on uncoated copper grids, routinely stained with saturated uranyl acetate in absolute methyl alcohol for 1 hour, dried in the dessicator, and screened in the A.E.I. E.M.6 ultramicroscope at the A. and R.C. Unit at St. Thomas's Hospital Medical School. In some cases ultrathin sections were stained with 0.25 and 0.5 per cent. aqueous solutions of phosphotungstic acid for times ranging from 1 to 12 hours, in lead acetate solution (Karnovsky, 1961) and in 1 per cent. potassium permanganate solution.

\section{Results}

Except in one specimen where the capsular region of the nodule alone was present, the biopsy material and the paraffin and ultrathin sections all included a part, at least, of the necrotic centre of the nodule. In many of the ultrathin sections there were also portions of the palisade layer.

In the histological sections, the necrotic centre, in all cases, showed a mixture of collagen, reticulin bundles, granular debris, fibrinoid or fibrin, and a few irregularly-shaped fragmented and pyknotic nuclei. The collagen and fibrinoid were well differentiated in the sections stained with azo-carmine and with phosphotungstic acid-haematoxylin (Figs 1, 2, and 3).

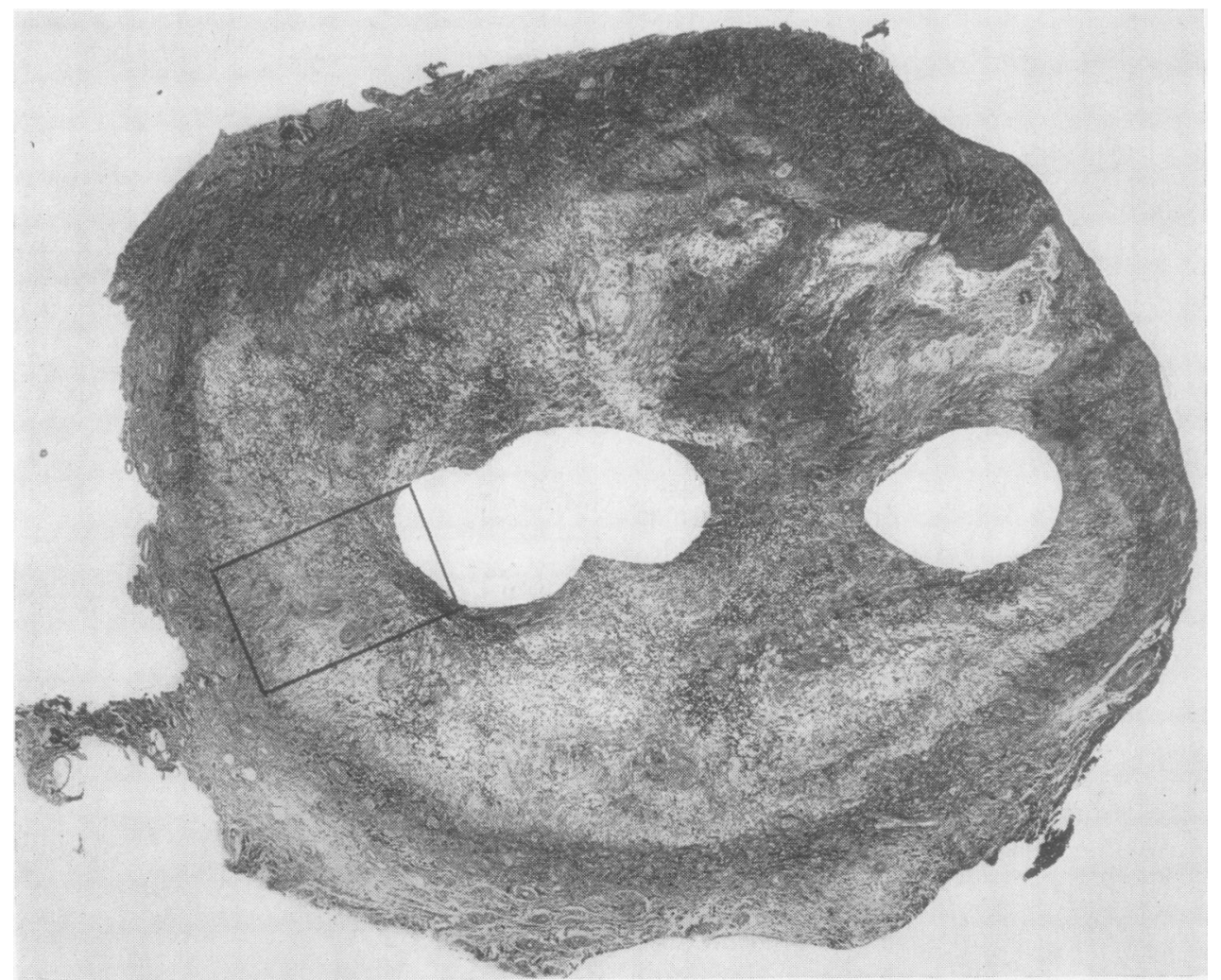

Fig. 1.-Section across whole nodule in Case 6. Two punch holes indicate the portions removed for electron microscopy; both are wholly within the necrotic centre. Surrounding this is a densely cellular band, indicating the limits of the latest extension of the necrotic process. Stained with azan-carmine. The fibrinoid stains red but appears black in the print. $\times 18$.

Fig. 2.-Higher-power view of the portion of the nodule enclosed in the rectangle of Fig. 1, showing the intermingling of the fibrin (darkly stained) and collagen. The arrow marks the palisade layer (lightly stained). Note the ghosts of blood vessels. Stained with azancarmine. $\times 85$. (p. 347 , above).

Fig. 3.-Same field as Fig. 2, stained with Mallory's phosphotungstic acid haematoxylin, showing a fibrinoid staining as fibrin (dark purple shown as black) against a background of collagen (brown, shown as grey). The arrow marks the palisade layer. $\times 85$. (p. 347 , below). 

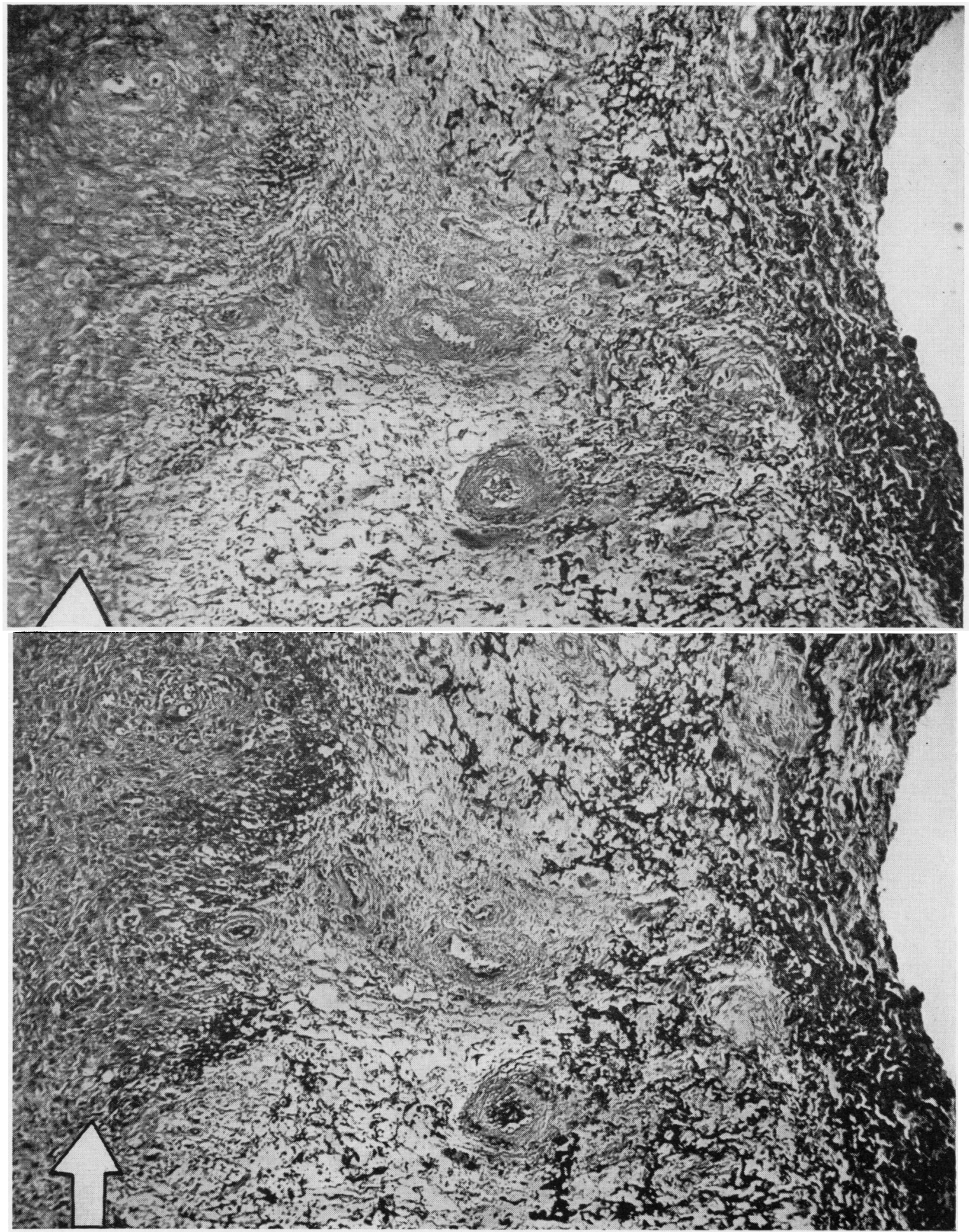

윰

훙 


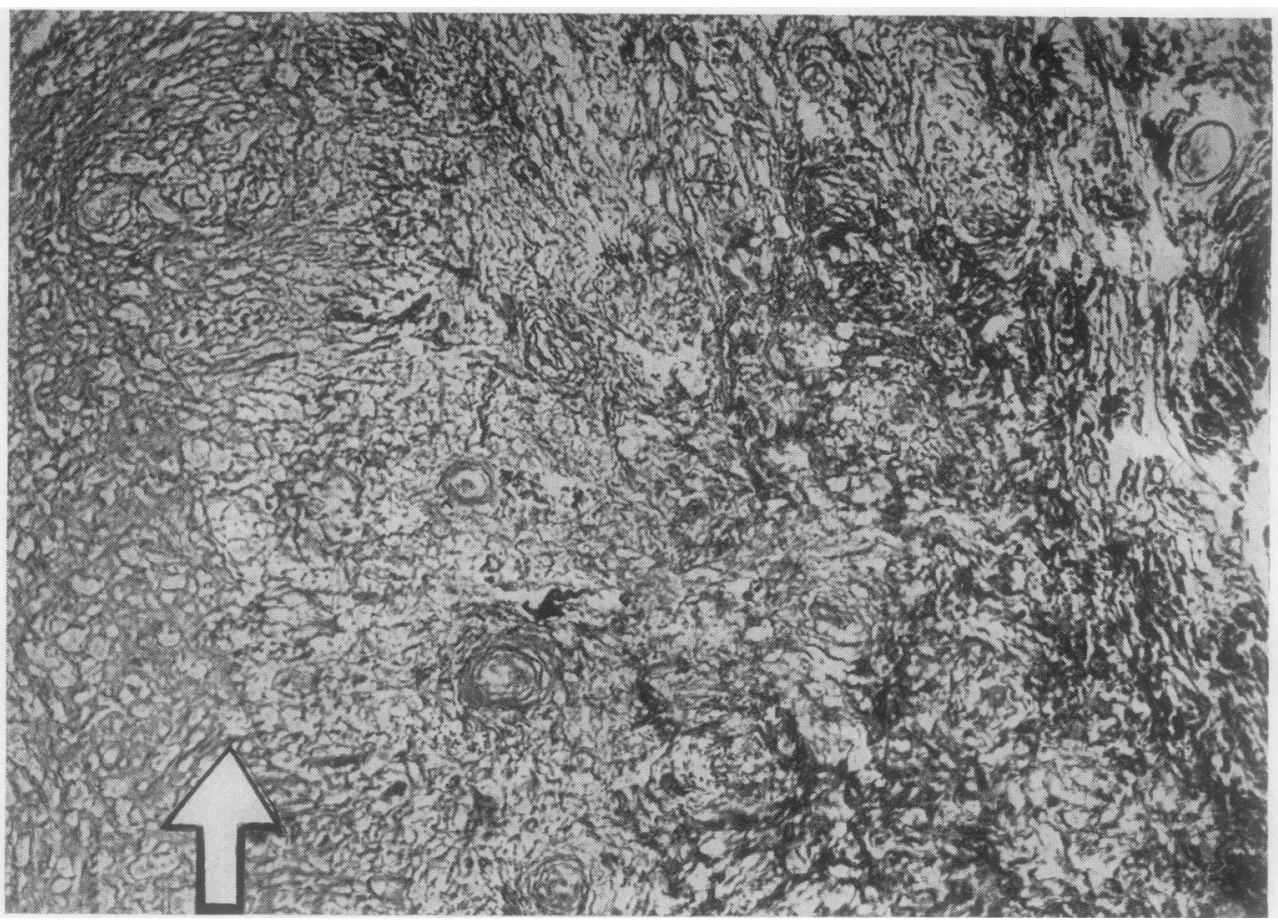

Fig. 4.-Similar field to Fig. 2 stained for reticulin which appears as black radially-distributed strands. Arrow marks palisade layer. $\times 85$.

The ghosts of necrotic blood vessels could also be identified in the central area. The reticulin fibres were connected with those between the cells of the boundary zone and were arranged radially (Fig. 4).

In the $1 \mu$ sections stained with Mallory's azure II-methylene blue mixture, the fibrinoid appeared as dark blue tracts and islands on a lighter blue background of stained collagen and cell debris (Fig. 5, opposite).

Scattered throughout the section were dark bluegreen spherical masses, believed to be fat globules. They corresponded in distribution and number with the scattered fat globules of the necrotic centre and palisade layer in sections coloured with Scharlach $\mathbf{R}$ (Fig. 6, opposite).

In the necrotic centre the fat globules were usually unrelated to cells (in the palisade layer some globules appeared to be extracellular but most were intracellular). Cholesterol crystals were a notable feature in Case 5.

The electron micrographs confirmed the presence, in the necrotic centre, of collagen fibres in varying amounts. In addition there was much scattered non-collageneous filamentous material, some electron dense and some less so, granular debris, cell organelles, fat globules, and some cells with complete plasma membrane (Figs 7 and 8 , overleaf). The collagen fibres occurred both singly and in bundles and considerable lengths of fibre could usually be followed in a single field. In places, however, only short lengths, often sharply angulated and devoid of any predominant bundle orientation, were present (Fig. 9, overleaf). Many collagen fibres were about $500 \AA$ in diameter and showed the normal periodic banding of mature collagen at about $640 \AA$. Sub-banding at intervals of approximately $120 \AA$ was frequently seen. However, most of the collagen fibres were of a more immature type. They measured about $300 \AA$ in diameter and showed periodic banding at intervals of about $140 \AA$ with no evidence of major and minor periods. These may correspond to "reticulin" fibres, which are known to consist of collagen by $x$-ray diffraction. In Case 3, of 9 years' standing, much thicker collagen fibres than normal were scattered amongst the more mature type (Fig. 9). These thick fibres measured about $1,200 \AA$ in diameter but possessed the normal $640 \AA$ banding. This material came from the thickened wall of an olecranon bursa.

Fig. 5.-1 $y$ section of the tissue removed from Case 6 for electron microscopy. Stained with Mallory's azure II-methylene blue. The darker tracts are believed to be fibrinoid. $\times 640$. (p. 349, above).

Fig. 6. - Part of the palisade layer and necrotic centre (Case 6) stained with Scharlach $R$ to show distribution of fat. $\times 210$. (p. 349, below) 

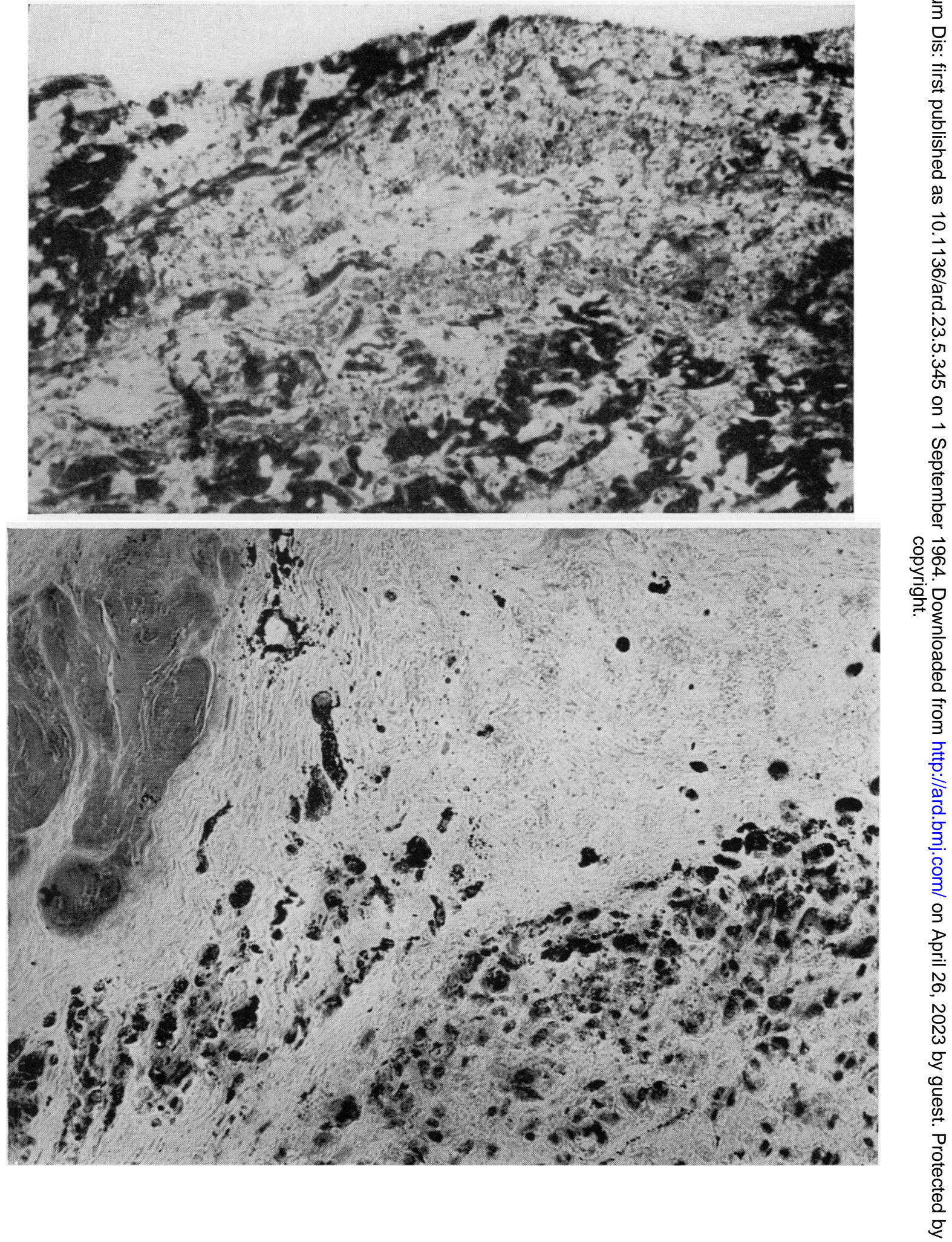


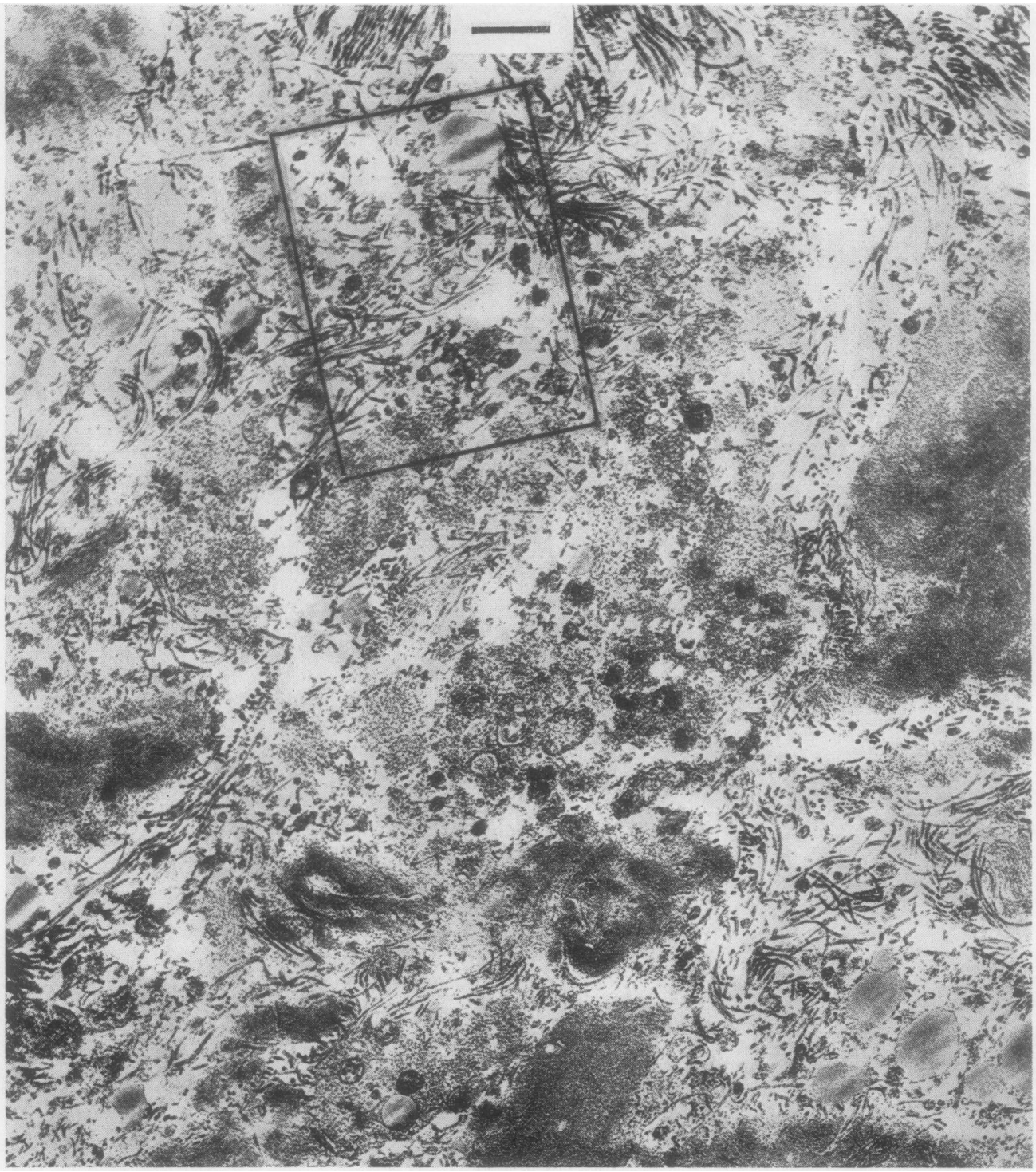

Fig. 7.-Electron micrograph (Case 6), showing general appearance of necrotic centre. There are abundant collagen fibres. (Scale marker $1 \mu$ ). 


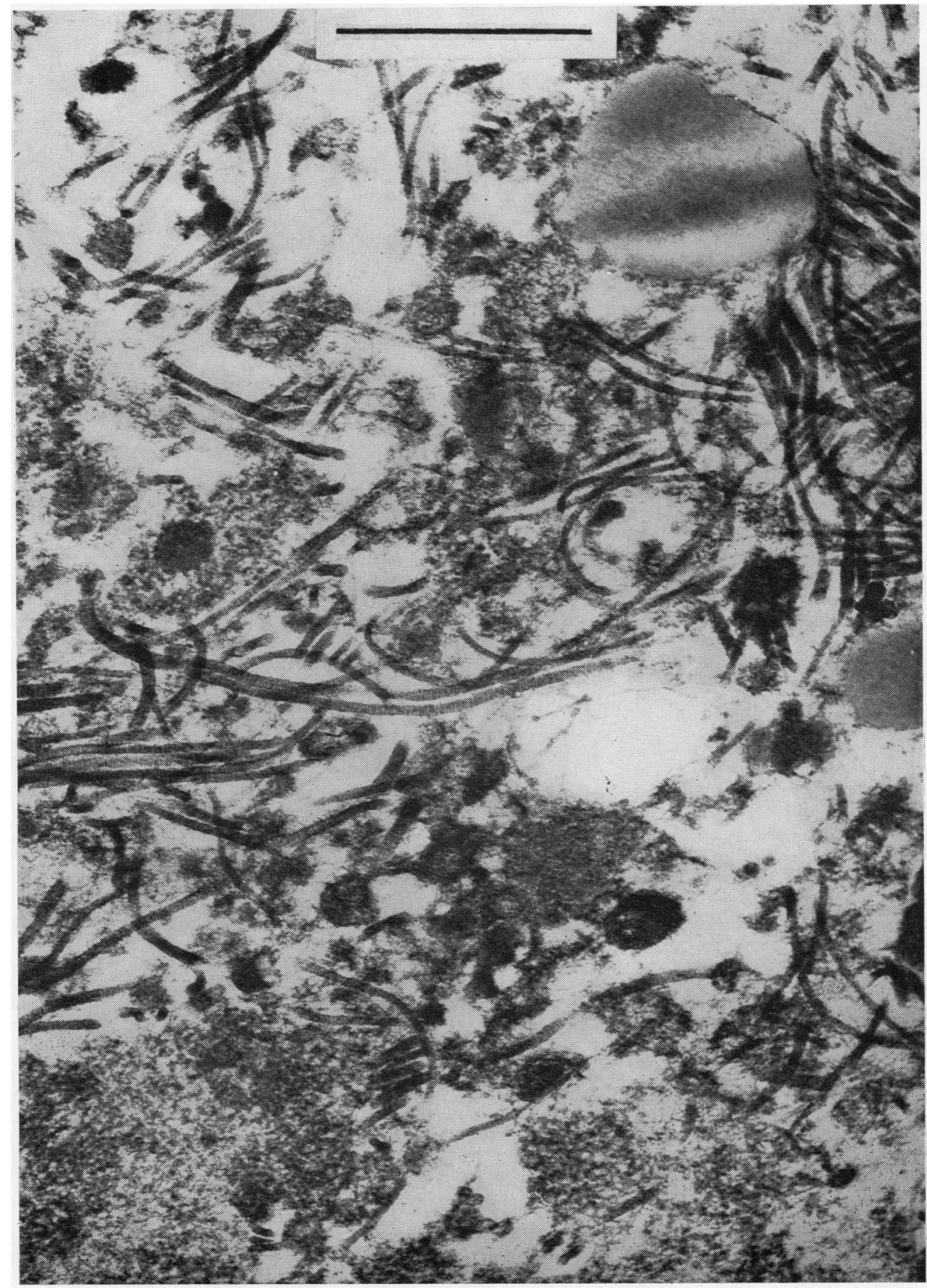

Fig. 8.-Higher magnification (Case 6) of area inset in Fig. 7. The periodic banding of the collagen, scattered cytoplasmic remnants, and fat globules are easily recognized. (Scale marker $1 \mu$ ). 


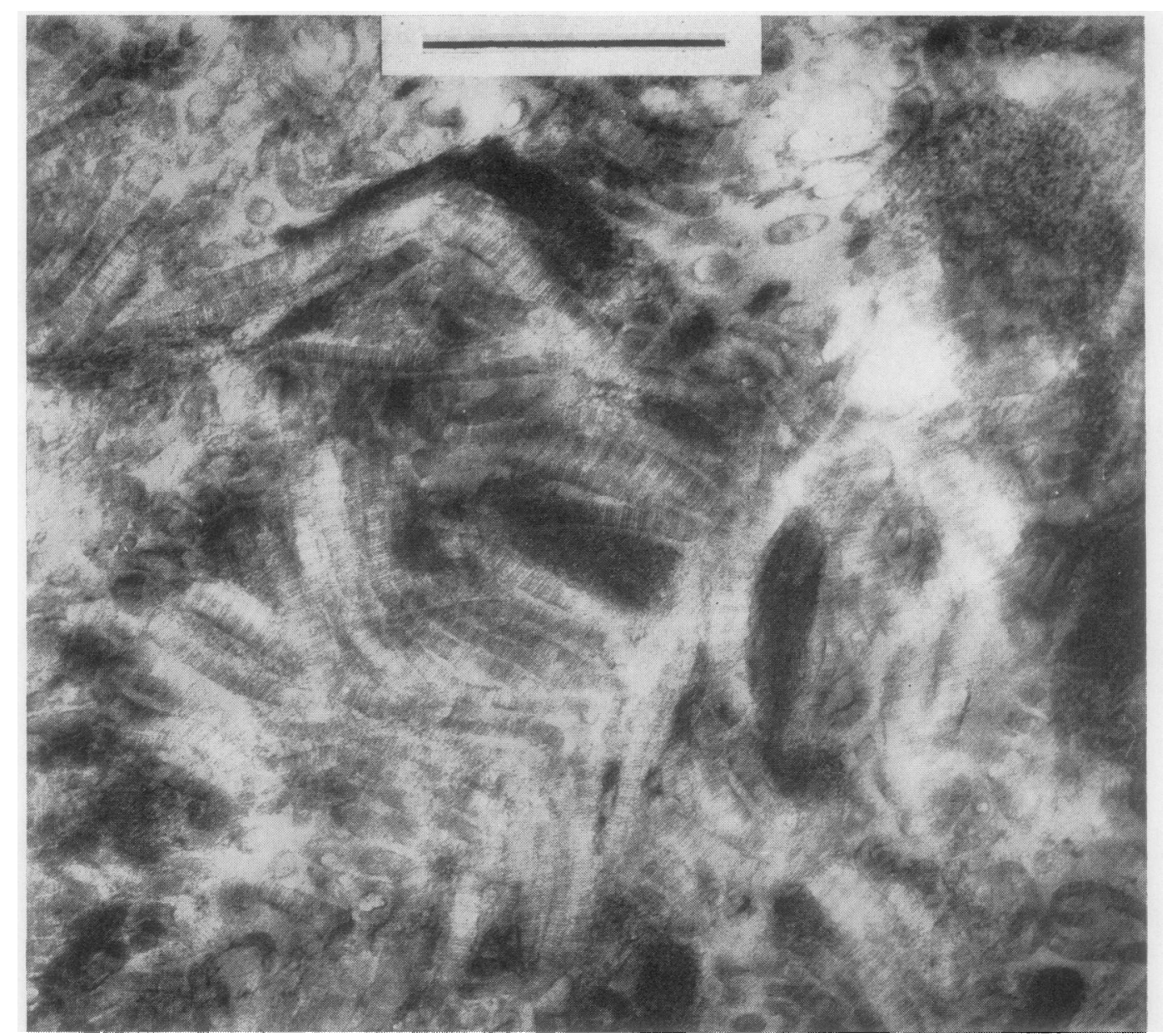

Fig. 9.-Electron micrograph, showing collagen fibres in disarray in necrotic centre. Many of the fibres show sharp angulation along their length. Some fibres are particularly thick but possess the normal banding of mature fibres. (Scale marker $1 \mu$ ).

The collagen fibre sizes and periodicity in the individual cases are recorded in Table II.

TABLE II

COLLAGEN. FIBRE DIAMETERS AND PERIODICITY

\begin{tabular}{|c|c|c|c|}
\hline Case No. & Fibre Diameter $\AA$ & Periodicity Å & Remarks \\
\hline $1^{*}(1)$ & $\begin{array}{l}300-500 \\
580\end{array}$ & $\begin{array}{l}100 \\
600\end{array}$ & $\begin{array}{l}\text { No } 640 \AA ̊ \text { banding seen } \\
\text { Fibres very uniform in size }\end{array}$ \\
\hline 2 & - & - & - \\
\hline 3 & $500-800$ & 100 & $\begin{array}{l}\text { Main } 640 \AA \text { banding occasionally seen } \\
\text { Some very thick fibres of } 1,200 \AA \text { diameter, } \\
\text { with the normal } 640 \AA \text { banding }\end{array}$ \\
\hline 4 & $\begin{array}{c}440-580 \\
\text { (bias to smaller diameter) }\end{array}$ & 100 & $640 \AA ̊$ banding not seen \\
\hline 5 & 400 & 100 & $640 \AA ̊$ banding seldom clearly seen \\
\hline $6^{*}(1)$ & $\begin{array}{l}300-800 \\
300\end{array}$ & $\begin{array}{c}640 \text { with sub-banding at about } 100 \AA \\
100\end{array}$ & $\begin{array}{l}\text { Main banding at } 640 \AA \AA \text { on thicker fibres } \\
\text { No main banding }\end{array}$ \\
\hline 7 & $260-520$ & 100 & $640 \AA ̊$ banding rarely seen \\
\hline
\end{tabular}

* Two different regions in the necrotic centre were examined. 


\section{ULTRAMICROSCOPIC STRUCTURE OF THE RHEUMATOID NODULE}

The denser filamentous material in the necrotic centre was identified with the so-called fibrinoid material of histological sections (Fig. 10). The filaments were about $600 \AA$ long and $50 \AA$ wide. They showed irregularly spaced densities along their length, usually at intervals of about $155 \AA$.

At the periphery of the necrotic centre this filamentous material was often seen to extend amongst the innermost cells of the palisade layer.

In addition to fibrinoid, a considerable amount of coarse granular material of similar electron density to cytoplasm was scattered throughout the necrotic centre. Dispersed in this were electron dense bodies often membrane-bound of about $330 \mathrm{~m} \mu$ diameter, resembling lysosomes, fat globules, and mitochondria. The fat globules varied in number and were

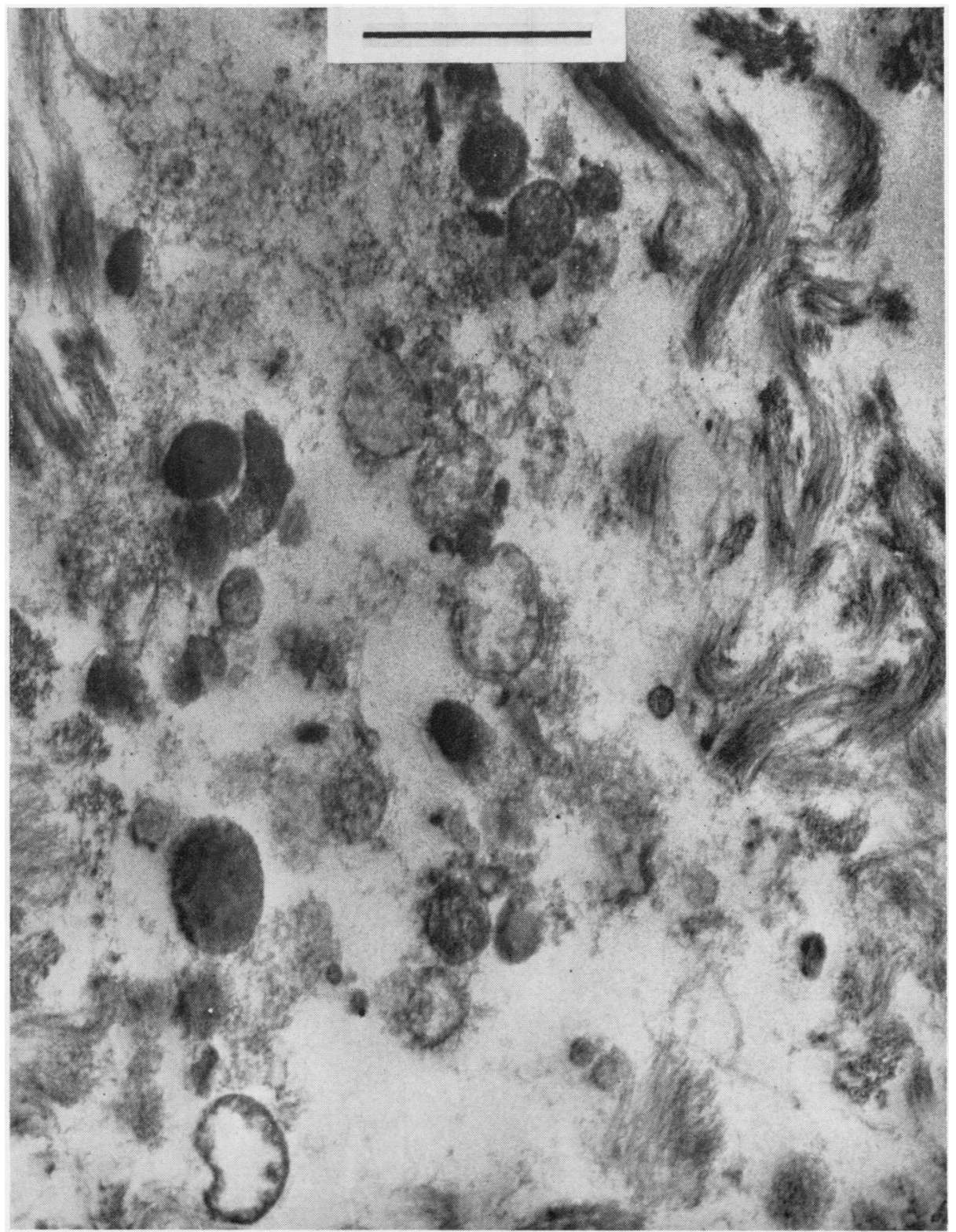

Fig. 10.-Electron micrograph (Case 1), showing filamentous nature of fibrinoid together with scattered cell debris. Mitochondria, vesicles, and dense bodies of cellular origin are identifiable. (Scale marker $1 \mu$ ). 
usually surrounded by a narrow rim of dense granular material. The mitochondria possessed thickened electron dense walls and stunted, stubby cristae (Fig. 10). In places their membranes could be resolved into two dark osmiophilic layers separated by an electron translucent lamina. Their contents were electron translucent so that they resembled empty bags. Some vesicles devoid of identifiable cristae were also present; some of these could be further stages in the degeneration of the mitochondria whilst others might be cytoplasmic vesicles released from a disintegrated parent cell. No evidence of typical Golgi apparatus, endoplasmic reticulum, or ribosomes was found in this cellular debris and no recognizable nuclei or nuclear material was seen. Membrane-bound masses of cytoplasm, devoid of nuclei but containing a variety of vesicles and some dense spherical bodies up to $0.5 \mu$ in diameter were also present. They were considered to be cell fragments which had not yet undergone complete disintegration with resultant widespread dispersal of their constituents (Fig. 11).

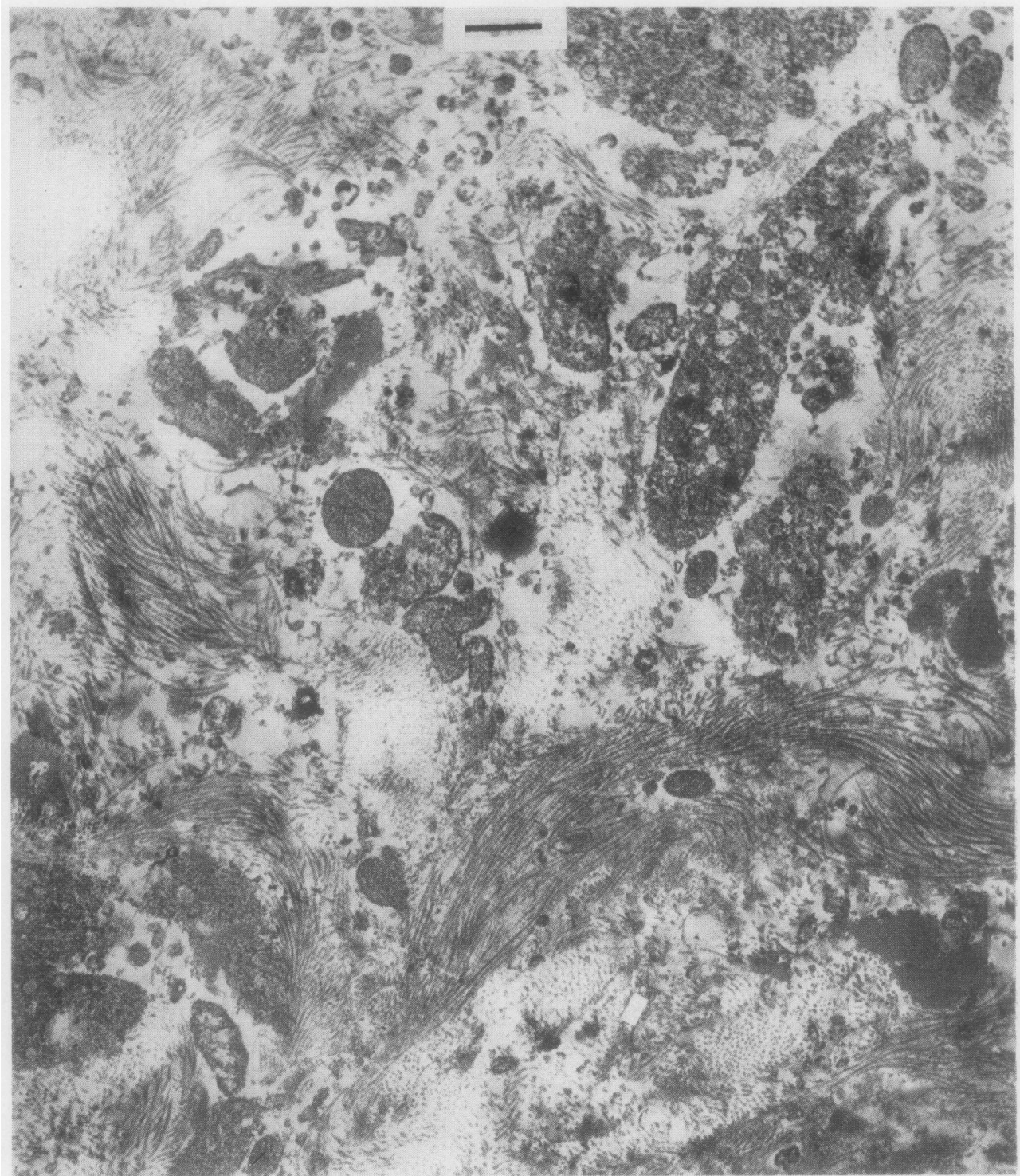

Fig. 11.-Electron micrograph of part of the necrotic centre in Case 5, showing widely scattered fragments of cells. (Scale marker $1 \mu$ ). 
In the cells with intact plasma membranes in the necrotic centre there were nuclei, mitochondria, and irregular vesicles. Their plasma membranes were often granular, in places a dense double-contoured membrane with an intervening electron translucent layer was visible. The cytoplasmic matrix was usually filamentous and contained large irregular vacuoles of varying sizes from about $0 \cdot 1$ to $2 \mu$ in largest dimension. The intracytoplasmic filaments measured up to $1 \mu$ in length and $60 \AA$ diameter, but showed no preferential distribution in the cytoplasm. They often occurred in pairs or bundles (Fig. 12).

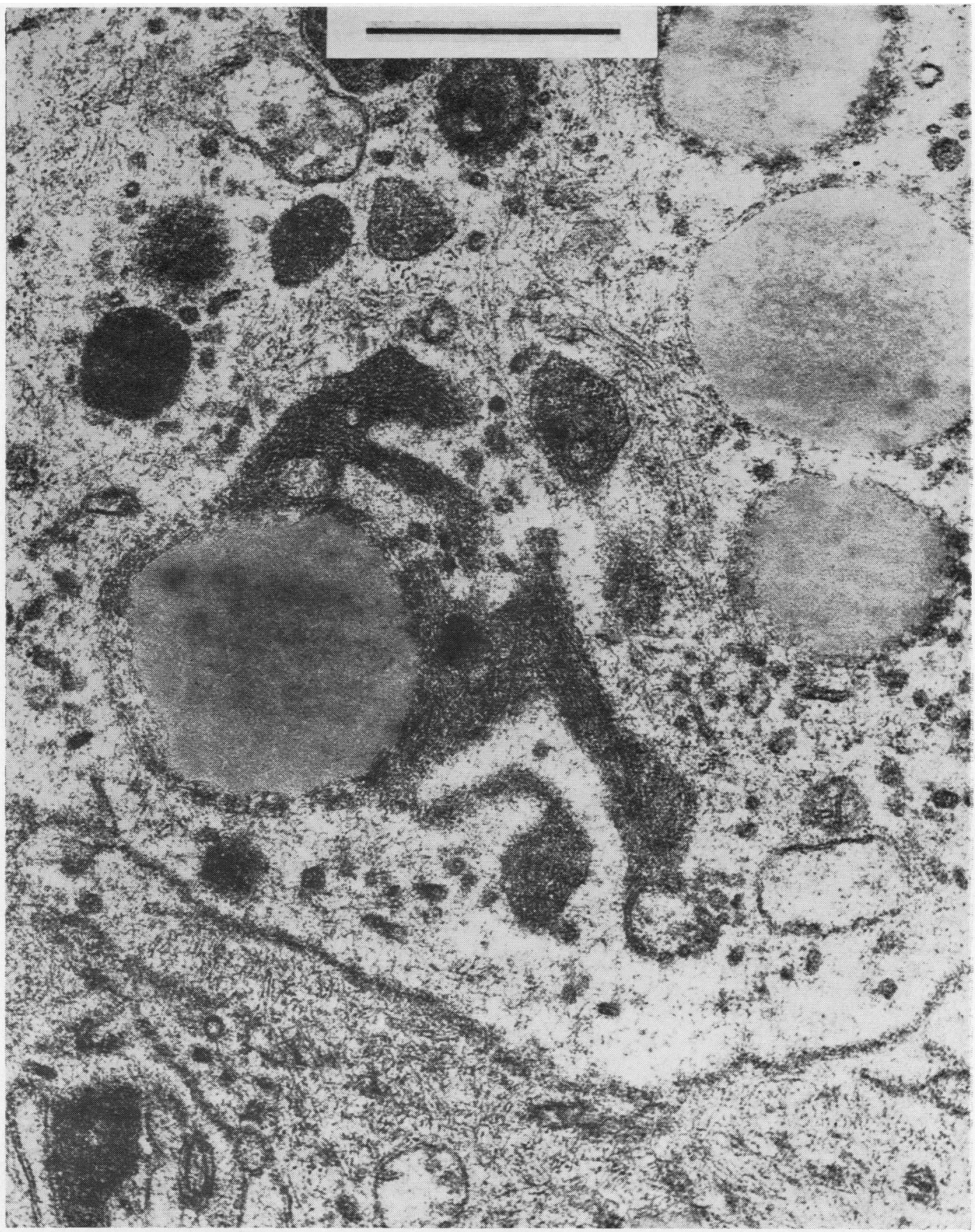

Fig. 12.-Electron micrograph (Case 6) of necrotic centre, showing the intracytoplasmic filamentous material in intact cells. (Scale marker $1 \mu$ ). 
The mitochondria possessed electron dense walls and a few, usually two or three, irregular cristae. Their contents were electron dense. Ribosomes were rarely seen and when present were few in number and irregularly scattered in the cytoplasm. Some cells however did contain rough-walled endoplasmic reticulum (Fig. 13), but in general the absence of cytomembranes was characteristic.

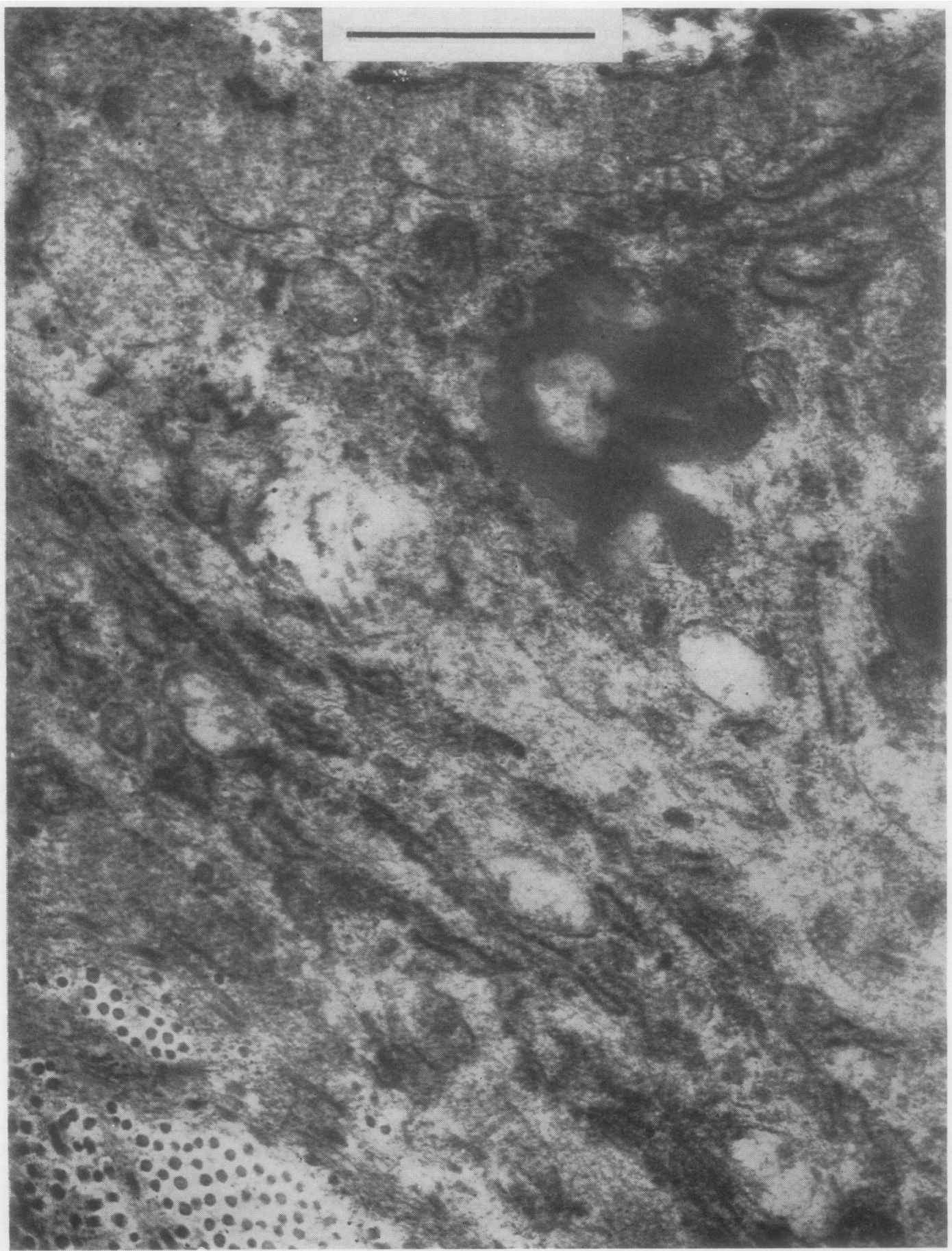

Fig. 13.-Electron micrograph of part of a cell from necrotic centre (Case 6), showing rough-walled endoplasmic reticulum, some irregular masses of fat, and enlarged mitochondria with distorted cristae. (Scale marker $1 \mu$ ). 
A Golgi apparatus was not seen in cells in the necrotic centre. The nucleus was usually coarsely granular and its surface was irregularly crenated. Nucleoli were not usually distinguishable, and the normal trilaminar structure of the nuclear membrane could rarely be resolved. A few small fat globules often occurred in cytoplasm; in Case 4 there were dense, vesicular, osmiophilic bodies in profusion in all the cells of the necrotic centre. These resembled the lipochondria described elsewhere (Cochrane, Davies, Palfrey, and Stockwell, 1964). They measured from 0.3 to $2 \mu$ in diameter (Fig. 14). Some consisted of

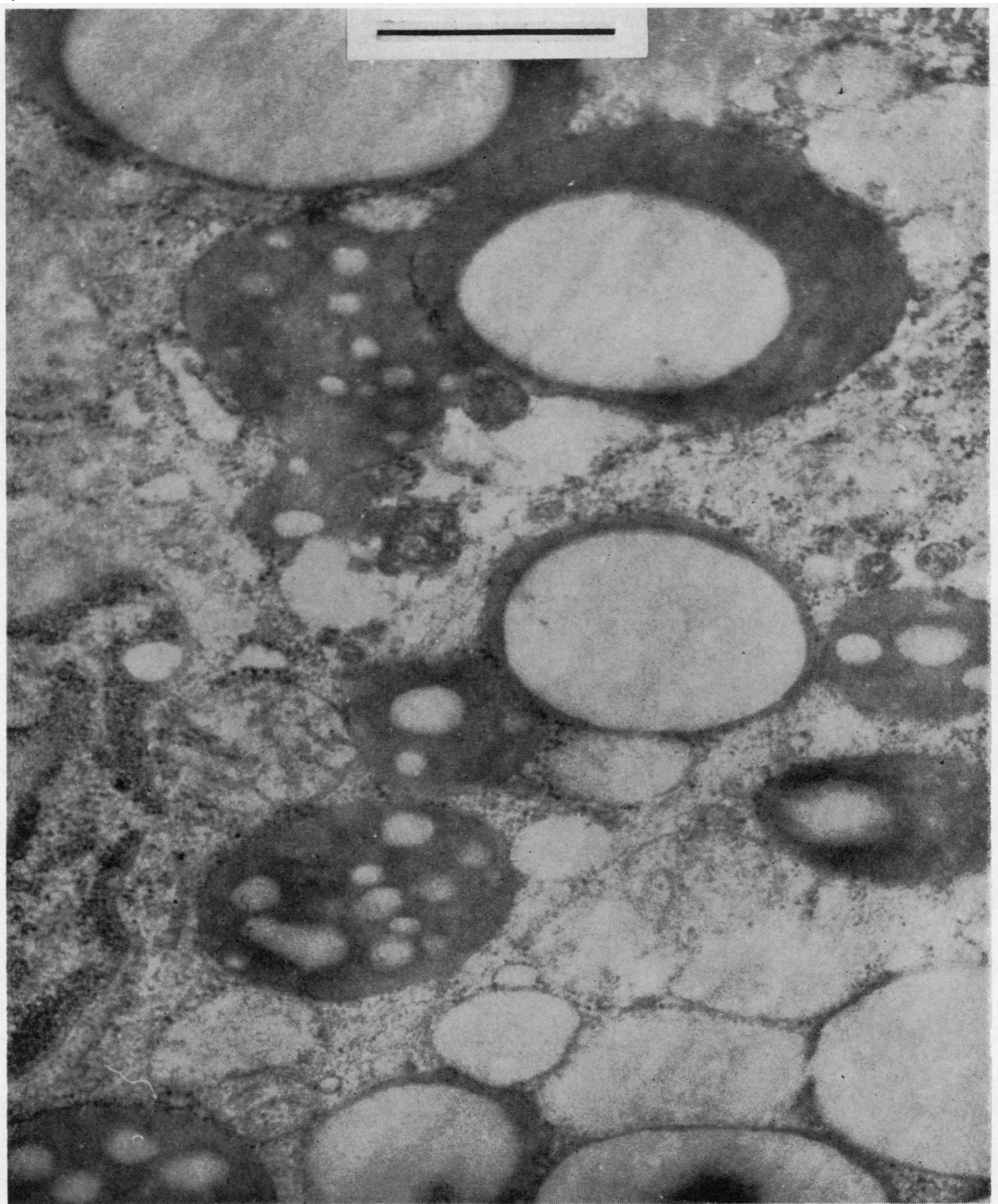

Fig. 14.-Electron micrograph of part of a cell from Case 4, showing vesicles surrounded by a thick electron dense wall and multivesicular bodies. (Scale marker $1 \mu$ ). 
single large vesicles surrounded by thick dense osmiophilic walls, others were dark osmiophilic masses containing several small electron translucent, oval, or circular vesicles, the largest of which were about $0 \cdot 3 \mu$ in greatest diameter. The appearance suggested that the smaller vesicles in the multivesicular variety coalesced to form the larger single vesicle bounded by a rim of osmiophilic material. Scattered amongst these vesicular osmiophilic bodies were some mitochondria, small amounts of roughwalled endoplasmic reticulum, and a few scattered ribosomes which in places were arranged at the surface of the osmiophilic bodies. These bodies were devoid of a limiting membrane.

Some of the apparently unbroken cells in the necrotic area contained concentrically-laminated and whorled myelin formations, dense granular bodies, usually few in number, and large membrane-bound vesicles containing a small amount of granular material. These vesicles which were irregular in shape and variable in size, up to $2 \mu$ in greatest length, might represent the dilated endoplasmic cisternae of degenerate cells.

A subjective assessment of the various components of the necrotic centre in the individual cases as judged from the light microscope studies and from the electron micrographs is given in Table III. No gold particles were seen in this region in Cases 3 and 5 , and no characteristic difference in the composition of the necrotic centre of the nodule was found in those cases which had received steroid therapy (Cases 4, 5, 6).

In the palisade layer the cells were closely apposed and little collagen or matrix separated them (Fig. 15 , opposite).

Their plasma membranes were irregular and closely interdigitated with those of neighbouring cells. Their nuclei contained well-marked nucleoli.

Some of these cells were fibroblasts which contained abundant and rough-walled endoplasmic reticulum and a well-developed Golgi apparatus. Others were probably histiocytes; these were irregular in outline and closely apposed. Their cytoplasm was provided with numerous spherical mitochondria with short stubby cristae and small amounts of finely granular matrix of varying electron density. A Golgi apparatus was frequently seen and large numbers of membrane-bound granular bodies of varying density, usually less than $0 \cdot 3 \mu$ in diameter, were scattered through the cytoplasm. They contained few cytomembranes and the ribosomes occurred in clumps scattered through the cytoplasm which was either filamentous or coarsely granular. Many of the cells of the palisade layer contained thin unbanded filaments which were of similar dimensions to those found in the cells of the necrotic zone.

The relatively few collageneous fibres in the palisade layer were of small diameter and banded at intervals of $640 \AA$. Bundles of these could be the

TABLE III

ASSESSMENT OF COMPOSITION OF TISSUE EXAMINED IN THE NECROTIC CENTRE

\begin{tabular}{|c|c|c|c|c|c|c|c|c|c|}
\hline Case No. & Component & . & Collagen & Fibrin & $\begin{array}{l}\text { Nuclear } \\
\text { Debris }\end{array}$ & $\begin{array}{l}\text { Other Cell } \\
\text { Debris }\end{array}$ & Fat & Oedema & Remarks \\
\hline & Rating $\ldots$ & $\cdots$ & $0-3$ & $0-3$ & $0-3$ & $0-3$ & $0-3$ & & \\
\hline 1 & $\mathrm{~L}$ & & $\begin{array}{l}1 \\
3\end{array}$ & $\begin{array}{l}3 \\
2\end{array}$ & $\begin{array}{l}2 \\
2\end{array}$ & $\overline{2}$ & Trace & - & \\
\hline 2 & $\mathrm{~L}$ & & & & Capsular r & n of nodule & & & \\
\hline 3 & $\mathrm{~L}$ & & $\begin{array}{l}3 \\
3\end{array}$ & $\begin{array}{l}1 \\
1\end{array}$ & $\begin{array}{l}1 \\
1\end{array}$ & $\overline{2}$ & $\overline{2}$ & $\begin{array}{l}0 \\
0\end{array}$ & $\begin{array}{l}\text { Specimen } \\
\text { entirely necrotic }\end{array}$ \\
\hline 4 & $\mathrm{~L}$ & & $\begin{array}{l}1 \\
2\end{array}$ & $\begin{array}{l}1 \\
0\end{array}$ & $\begin{array}{l}0 \\
1\end{array}$ & $\overline{3}$ & $\begin{array}{c}\text { Ch.c. } \\
3\end{array}$ & $\underline{0}$ & $\begin{array}{l}\text { Specimen } \\
\text { entirely necrotic }\end{array}$ \\
\hline 5 & $\begin{array}{ll}\mathrm{L} & (1) \\
\mathrm{E}\end{array}$ & & $\begin{array}{l}1 \\
1 \\
3\end{array}$ & $\begin{array}{l}3 \\
0 \\
3\end{array}$ & $\begin{array}{l}1 \\
0 \\
0\end{array}$ & $\overline{2}$ & Ch.c. 3 & $\begin{array}{r}1 \\
0 \\
-\end{array}$ & \\
\hline 6 & $\mathrm{~L}$ & & $\begin{array}{l}1 \\
3\end{array}$ & $\begin{array}{l}3 \\
3\end{array}$ & $\begin{array}{l}0 \\
1\end{array}$ & $\overline{3}$ & $\begin{array}{l}2 \\
2\end{array}$ & $\underline{2}$ & \\
\hline 7 & $\begin{array}{ll}\mathrm{L} & (1) \\
\mathrm{E}\end{array}$ & & $\begin{array}{l}3 \\
3 \\
3\end{array}$ & $\begin{array}{l}1 \\
2 \\
1\end{array}$ & $\begin{array}{l}0 \\
1 \\
3\end{array}$ & $\overline{1}$ & $\overline{1}$ & $\begin{array}{r}0 \\
0 \\
-\end{array}$ & $\begin{array}{c}\text { Early } \\
\text { nodule }\end{array}$ \\
\hline
\end{tabular}

$\mathrm{L}=$ Light microscopy: $\quad \mathrm{E}=$ Electron microscopy: $\quad$ Ch.c. $=$ Cholesterol clefts.

Increasing amounts of a component are indicated by higher numbers. 


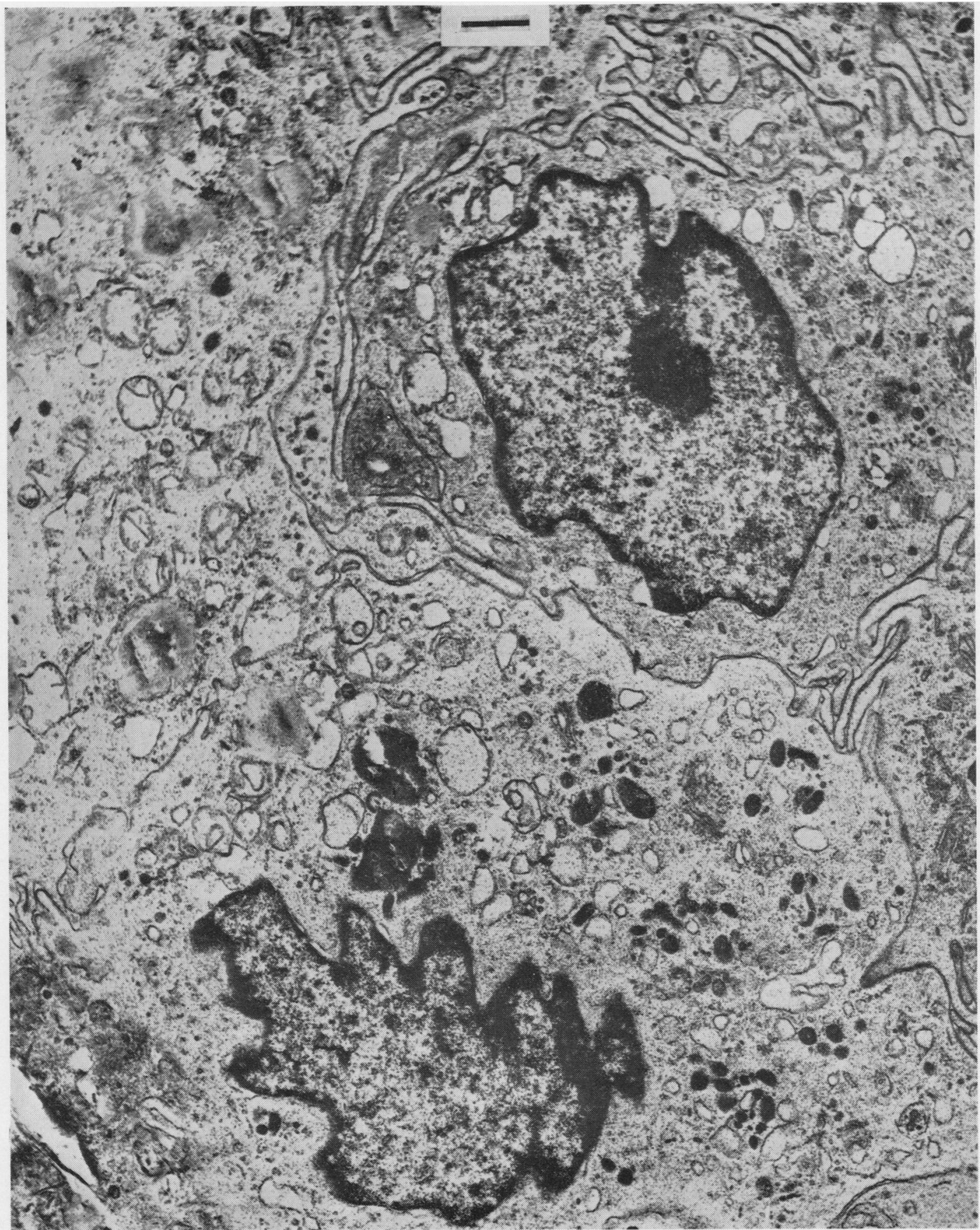

Fig. 15.-Electron micrograph of part of palisade layer in Case 5. (Scale marker $1 \mu$ ). 
reticulin fibres seen with the light microscope. There were also irregular areas of dense, finely granular material, extracellular and intimately mixed with the banded bundles of collagen or reticulin fibres (Fig. 16, opposite). It is thought that this material corresponded with the fibrinoid seen in the light microscope which, as shown in Figs 2 and 3, often extended widely between the cells of the palisade layer. Polymorphonuclear leucocytes were an unusual feature in this layer and no mast cells were seen.

\section{Discussion}

The necrotic centre of the rheumatoid nodule includes a variety of constituents varying in proportions from one part of the centre to another and from one nodule to another. These include:

(1) Cellular remnants, granular material of an unidentifiable nature, and fat globules;

(2) Collagen and reticulin fibres;

(3) Non-collageneous filamentous material.

The apparently intact cells all show damage or degeneration, ribosomes are scanty and a classical Golgi apparatus is not discernible. Changes interpreted as degenerative are seen in the nuclei and mitochondria and there are fat globules and lipochondria-like bodies in the cytoplasm. Bodies of the latter type have been found in both normal and abnormal cells (Lever, 1955; Policard, Collet, and Prégermain, 1958; Cochrane and others, 1964), but there are as yet few constructive suggestions as to their nature. Whether the clear vesicular regions in the lipochondria represent pre-existing vesicles, or areas where fat of a different nature has been dissolved out in the preparation of sections, or areas containing some substance which is not osmiophilic but nevertheless forms an integral part of the body, is undecided.

The cells of the necrotic centre are judged to be dead; they have lost their staining properties in histological sections but the electron micrographs show that they still preserve a considerable degree of recognizable internal structure. The plasma membranes can rarely be resolved into the trilaminar structures seen in normal cells and are usually coarsely granular. The amount of cellular debris in the necrotic centre suggests that this region has at one time been in large measure cellular. The appearance of the cells in the necrotic centre, however, is in sharp contrast to that of the cells in the palisade layer which have an internal structure suggesting considerable activity. The latter may be concerned in the production of some of the constituents of the necrotic centre to which they are adjacent. Their membrane-bound, electron dense bodies, may however be lysosomes, and these cells may be actively involved in the degradation of some constituent of the necrotic central area.

The characteristic feature of the collagenous fibres in the necrotic centre is the relatively high proportion of immature fibres and the normality of the morphological features of both the immature and mature elements. Some of the finer fibres might correspond to the argyrophilic fibres seen in silver-impregnated material (Kellgren and others, 1951; Kellgren, 1952). There is no evidence in the necrotic centre of disintegration of individual collagen fibres nor of swelling of these fibres as described in histological investigations. Indeed the majority of fibres are of smaller diameter than adult collagen fibres elsewhere. However, the bundles are often disrupted and occasional fibres in a bursal wall in one case are particularly thick but preserve the normal periodicity of mature collagen. The relative normality of the collagen fibres, whether immature or mature, agrees with the findings of Bien and Ziff (1951) who found a normal hydroxyproline content in the collagen fibres of the rheumatoid nodule.

The dispersed, fine, filamentous material amongst the collagen fibres in the palisade layer is very similar in appearance to that illustrated by Barland, Novikoff, and Hamerman (1962) amongst synovial cells. These authors make no comment as to its nature. The fine filaments are unlike the extracellular beaded filaments of over $100 \AA$ diameter described in fibrous tissue by Chapman (1962), in that the latter show a periodic beading at intervals of 500-600 $\AA$ and are identified as collagen. The fine filamentous material seen in the palisade layer may nevertheless represent some collagen precursor. It does not correspond morphologically to tropocollagen, which is characterized by Hall (1956) and Hall and Doty (1958) as composed of fibrous particles of about $15 \AA$ width and about $2,820 \AA$ in length. It is also possible that this filamentous material results from the precipitation of mucopolysaccharide or mucoprotein in the interfibrillar matrix of connective tissue.

The dense finely granular aggregates of material in the palisade layer correspond in distribution and quantity to the "fibrinoid" of the histological preparations. The aggregates are sufficiently large to be identified in the light microscope. The absence of a periodically-banded fibrous structure, however, raises a problem in identification (see Bywaters and Glynn, 1957). Kramer and Little (1953) and Sorenson (1960) stated that reticulin, in the human renal cortex and in the lymph nodes of rabbits respectively, consisted of fibrils with the same axial 


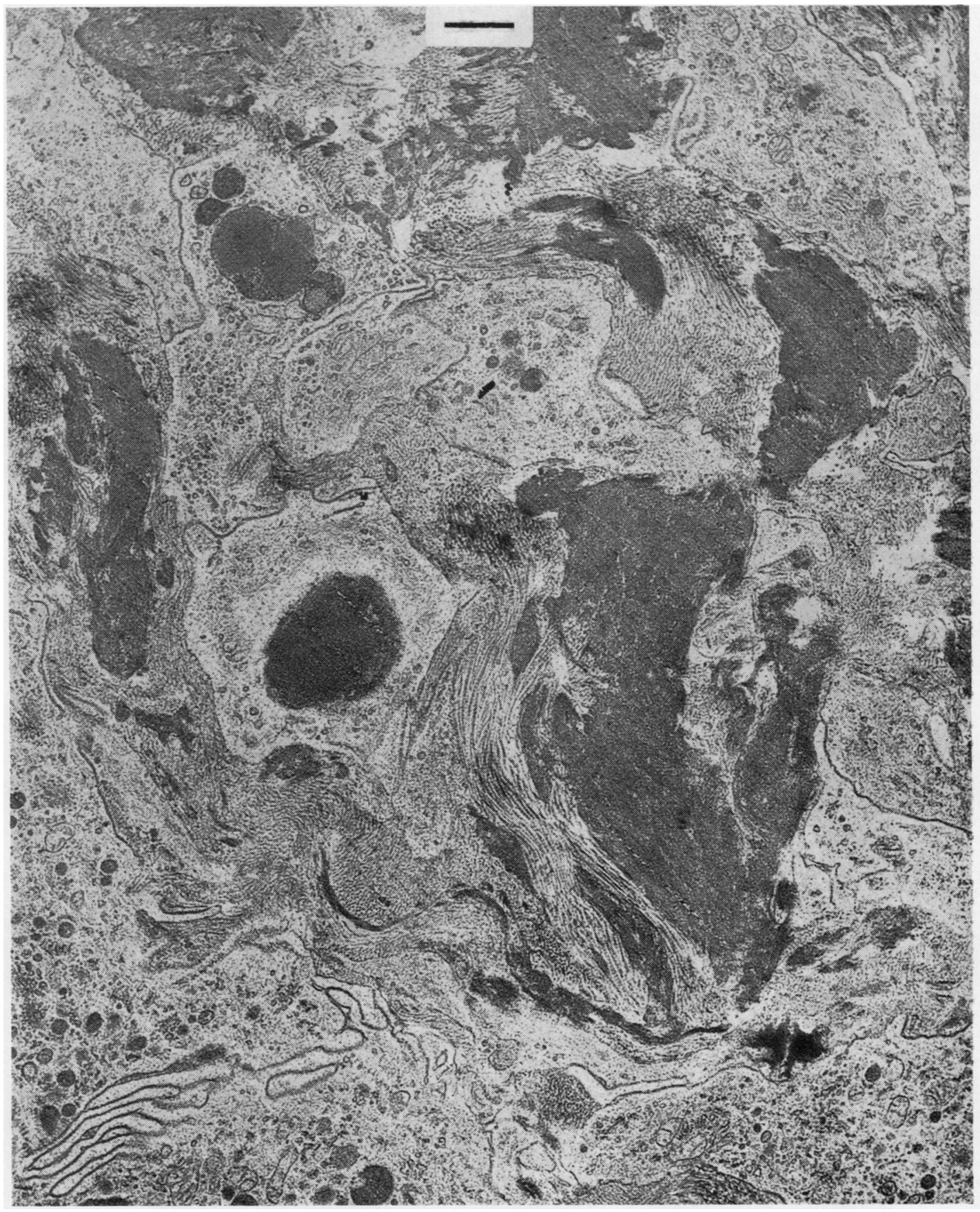

Fig. 16.-Electron micrograph, showing tracts of granular material believed to be fibrinoid, in palisade layer. (Scale marker $1 \mu$ ). 
periodicity as collagen. According to Sorenson these were associated with fine filaments and an amorphous material. Other investigators (Weiss, 1957; Stoeckenius, 1959; Galindo and Imaeda, 1962), on the other hand, described reticulin as a finely granular or amorphous material of moderate electron density. Galindo and Imaeda (1962) also included in this material occasional fibres of about $500 \AA$ in width with an axial periodicity of $600 \AA$, but Weiss (1957) and Stoeckenius (1959) did not describe any such fibres in their material. Our findings agree with those of the last-named investigators, but there is little doubt that further clarification concerning the electron microscopic appearances of reticulin from various situations is required.

It is difficult to avoid identification of the dense filamentous material in the necrotic centre and to a lesser extent in the palisade layer with fibrinoid. Material so designated and exhibiting histologically a homogeneous, refractile appearance with acidophilia is described in several situations including normal, pathological, and experimental tissues, but there is no certainty that it is identical in all these sites. In arteries it seems probable that smooth muscle contributes to it; in other situations it appears to be mainly fibrin as judged by tinctorial, histochemical, and immunological criteria. Histochemically, the material gives a positive P.A.S. reaction (Altshuler and Angevine, 1949) and may contain a considerable quantity of arginine as judged by the Sakaguchi reaction. Fluorescent antibody studies (Gitlin, Craig, and Janeway, 1957) show the presence of fibrin and of a small amount of $\gamma$-globulin. On fresh minced tissue, Kantor, Sokoloff, Smith, and Ziff (1951) found that fibrinoid was digested by trypsin but was resistant to hydrolysis with Clostridium Welchii collagenase. The histological and histochemical characters of fibrinoid in several situations, including the rheumatoid nodule, have been well reviewed by Movat and More (1957). The present observations support the view of these authors that fibrinoid does not result from swelling of collagen or of a component of the ground substance of connective tissue. Movat and More believe that fibrinoid is derived from a "conglomeration and homogenization" of a fibrinous exudation.

The dense filamentous material seen here by electron microscopy in the necrotic centre is not identical with the fibrin filaments described by Hawn and Porter (1947), which show a regular dark banding in stained sections with a periodic interval of about $250 \AA$. This periodicity has since been confirmed by Hall $(1949,1963)$ and by Bang, Fletcher, Alkjaersig, and Sherry (1962). Hall also describes a secondary lighter band between the dark striations.
Hall and Slayter (1959) describe the fibrinogen molecule as having a length of $475 \pm 25 \AA$ and consisting of three beads of about $65 \AA$ diameter united by a thin thread. The material described by the above investigators consisted of in vitro preparations. Fibrin produced by intravascular clothing in rabbits is described by Vassalli, Simon, and Rouiller (1963) as very electron dense and fibrillar; the less dense granular material in their lesions is designated fibrinoid. These authors do not state any axial periodicity on the fibrin filaments. They describe transitional forms between fibrin and fibrinoids and discuss the possible relationship between these two components. They mention that a periodicity was seen rarely but that, when present, it could not be measured with precision. If the identity indicated here is accepted, then the less dense filamentous material described in the present material might be fibrin undergoing degradation and be similar to the intracellular substance of decreasing osmiophilia described by Vassalli and others (1963).

However, the morphological characters of fibrin as observed in the electron microscope may vary with the method of formation, and further studies are required along these lines. An extensive study of fibrin formation under different physiochemical conditions and in different physiological or pathological states is required.

\section{Summary}

(1) The necrotic centre of six rheumatoid nodules has been examined histologically, histochemically, and by electron microscopy

(2) Collagen, mostly of the immature type, filamentous material, some electron dense and some less electron dense, cell debris, fat globules, and intact cells with unbroken cell walls were identified.

(3) The dense filamentous material is identified with the fibrinoid of light microscopy. It does not possess the morphology of in vitro preparations of fibrin but bears a close resemblance to the in vivo preparations described by other authors.

\section{REFERENCES}

Altshuler, C. H., and Angevine, D. M. (1949). Amer. J.Path., 25, 1061.

Bang, N. U., Fletcher, A. P., Alkjaersig, N., and Sherry, S. (1962). J. clin. Invest., 41, 935.

Barland, P., Novikoff, A. B., and Hamerman, D. (1962). J. Cell Biol., 14, 207.

Bennett, G. A., Zeller, J. W., and Bauer, W. (1940). Arch. Path., 30, 70. 
Bien, E. J., and Ziff, M. (1951). Proc. Soc. exp. Biol. (N.Y.), 78, 327.

Bywaters, E. G. L., and Glynn, L. E. (1957). "Miscellaneous Disorders of Metabolism. II. Connective Tissue Disorders", in "Biochemical Disorders in Human Disease", ed. R. H. S. Thompson and E. J. King, p. 623. Churchill, London.

Chapman, J. A. (1962). Brit. med. Bull., 18, 233.

Cochrane, W. Davies, D. V., Palfrey, A. J., and Stockwell, R. A. (1964). J. Anat.(Lond.), 98, 1.

Collins, D. H. (1939). Rheum. Dis., 1, 38.

Galindo, B., and Imaeda, T. (1962). Anat. Rec., 143, 399.

Gitlin, D., Craig, J. M., and Janeway, C. A. (1957). Amer.J. Path., 33, 55.

Hall, C. E. (1949). J. biol. Chem., 179, 857.

- (1956). Proc. nat. Acad. Sci. (Wash.), 42, 801. (1963). Lab. Invest., 12, 998. and Doty, P. (1958). J. Amer. chem. Soc., 80, 1269. and Slayter, H. S. (1959). J. biophys. biochem. Cytol., 5, 11.

Hawn, C. Van Zandt, and Porter, K. R. (1947). J. exp. Med., 86, 285.

Kantor, T., Sokoloff, L., Smith A., and Ziff, M. (1951). Ann. rheum. Dis., 10, 471.

Karnovsky, M. J. (1961). J. biochem. biophys., 11, 729.

Kellgren, J. H. (1952). Brit. med.J., 1, 1093, 1152.

—, Ball, J., Astbury, W. T., Reed, R., and Beighton, E. (1951). Nature (Lond.), 168, 493.

Kramer, H., and Little, K. (1953). "Nature of Reticulin", in "Nature and Structure of Collagen", ed. J. T. Randall and S. F. Jackson, p. 33. Butterworths, London.

Lever, J. D. (1955). Amer. J. Anat., 97, 409.

Movat, H. Z., and More, R. H. (1957). Amer. J. clin. Path., 28, 331.

Policard, A., Collet, A., and Prégermain, S. (1958). Bull. Micr. appl., ser. 2, 8, 88

Richardson, K. C., Jarett, L., and Finke, E. H. (1960). Stain. Tech., 35, 313.

Sokoloff, L., and Bunim, J. J. (1957). J. chron. Dis., 5, 668.
Sorenson, G. D. (1960). Amer. J. Anat., 107, 73.

Stoeckenius, W. (1959). Verhandl. dtsch. Ges. Path., 42, 351.

Vassalli, P., Simon, G., and Rouiller, C. (1963). Amer. J. Path., 43, 579.

Weiss, L. (1957). J. biophys. biochem. Cytol., 3, 599.

Zetterquist, H. (1956). "The Ultrastructural Organization of the Columnar Absorbing Cells of the Mouse Jejunum." Karolinska Inst., Stockholm.

\section{La structure ultramicroscopique du nodule rhumatoïde}

\section{RÉSUMÉ}

(1) On a examiné le centre nécrotique de six nodules rhumatoïdes histologiquement, histochimiquement et au microscope électronique.

(2) On a identifié le collagène, surtout du type immature; du matériel filamenteux électroniquement plus ou moins épais; des débris cellulaires; des globules graisseux; et des cellules intactes aux parois inentamées.

(3) On identifie l'épais matériel filamenteux comme matériel fibrinoïde vu au microscope optique. Morphologiquement il ne porte pas le caractère des préparations de fibrine in vitro, mais ressemble beaucoup aux préparations in vivo décrites par d'autres auteurs.

\section{La estructura ultramicroscópica del nódulo} reumatoide

\section{SUMARIO}

(1) Se examinó el centro necrótico de seis nódulos reumatoides histológica, histoquímica y electron-microscópicamente.

(2) Se identificaron: colágeno, principalmente del tipo inmaduro; material filamentoso electrónicamente más o menos espeso; desecho celular; globulos de grasa; y células intactas con paredes íntegres.

(3) El material filamentoso espeso se identifica como material fibrinoide del microscopio óptico. Morfológicamente no tiene el aspecto de las preparaciones de fibrina in vitro, pero se parece mucho a las preparaciones in vivo mencionadas por otros autores. 